Ijtihad: Jurnal Wacana Hukum Islam dan Kemanusiaan

Vol. 21, No. 2 (2021), pp. 155-175, doi : 10.18326/ijtihad.v21i2.155-175

\title{
The constitutional rights of indigenous beliefs adherents in minority fiqh perspective
}

\author{
Gugun El Guyanie, Aji Baskoro
}

Universitas Islam Negeri Sunan Kalijaga Yogyakarta

E-mail:198503012018011002@uin-suka.ac.id,baskoro.ajibas@gmail.com

DOI: $10.18326 /$ ijtihad.v21i2.155-175

Indigenous Beliefs Adherents (Penghayat Kepercayaan) who were victims of injustice filed a judicial review and finally brought out to Constitutional Court Decision Number 97/PUU-XIV/2016. This decision became the legal basis for Indigenous Beliefs Adherents to obtain their constitutional rights: recognition, respect, and protection by embedding the beliefs they believe in on the electronic ID card (e-KTP). This study aims to analyze based on the epistemology of minority fiqh on the constitutional rights of Indigenous Beliefs Adherents. In contrast to many studies that place minority figh in defense of Muslim minorities in the West, this study develops minority fiqh for non-Muslim minorities in Muslim-majority countries. This article uses normative legal research, with qualitative descriptive analysis with a case approach that analyzes Constitutional Court Decision Number 97/PUU-XIV/2016. The study results show that the Constitutional Court Decision viewed from the perspective of minority fiqh is very relevant. Because the purpose of Islamic law is none other than to protect minorities, including freedom of religion. Minority figh is also in line with the concept of constitutional rights. The Constitutional Court Decision restores Indigenous Beliefs' constitutional rights to the same level as other religious groups.

Penghayat kepercayaan yang menjadi korban ketidakadilan mengajukan judicial review dan akhirnya melahirkan Putusan Mahkamah Konstitusi Nomor 97/PUU-XIV/2016. Putusan tersebut menjadi dasar hukum bagi penghayat kepercayaan untuk mendapatkan hak konstitusionalnya: pengakuan, penghormatan dan perlindungan dalam bentuk pencantuman kepercayaan yang mereka yakini pada KTP-el. Tujuan dari kajian ini adalah menganalisis dengan basis eistemologi fikih minoritas terhadap hak-hak konstitusional penghayat kepercayaan. Berbeda dengan banyak kajian yang menempatkan fikih minoritas untuk membela minoritas muslim di Barat, kajian ini mengembangkan fikih minoritas untuk minoritas nonmuslim di negara mayoritas muslim. Artikel ini menggunakan penelitian hukum normatif, dengan 
Ijtihad: Jurnal Wacana Hukum Islam dan Kemanusiaan, Volume 21, No. 2, Desember 2021: 155-175

analisis deskriptif kualitatif dengan case approach yang menganalisis Putusan MK Nomor 97/PUUXIV/2016. Hasil kajian menunjukkan bahwa putusan MK tersebut ditinjau dari perspektif fikih minoritas sangat relevan. Karena tujuan syari’at Islam tidak lain adalah untuk melindungi kaum minoritas, termasuk kebebasan beragama. Fikih minoritas juga selaras dengan konsep hak-hak konstitusional, yang dalam putusan MK, mengembalikan hak konstitusional penghayat kepercayaan setara dengan kaum beragama lainnya.

Keywords: constitutional rights; indigenous beliefs adherents; minority fiqh; penghayat kepercayaan

\section{Introduction}

Indonesia has the title as a country that practices discrimination in religion and belief, especially against religious minorities and groups of Indigenous Beliefs Adherents and indigenous peoples whose rights are marginalized (Budijanto, 2016, p. 36). How ironic when the state that should provide recognition, namely, honor and respect towards minority groups, instead marginalizes the rights of believers who have historical origins that lived long before the republic's independence.

Recognition in this context can be interpreted as acknowledging and respecting the state towards legal community units and minority groups and giving them the freedom to manage their household and traditional rights. Recognition also requires the right to practice the values and laws that apply to a traditional and customary law community or a minority group that communally has an exclusive identity from the majority. That community existed even earlier than the proclamation of independence (Dwipayana, 2011, pp. 1-4).

Indigenous Beliefs Adherents, that's commonly known in Indonesia as Penghayat Kepercayaan, are categorized as a minority group because, according to Max van der Stoel, there are two characteristics (Bober \& Berdiqulov, 2020, p. 3). First, a group with linguistic, ethnic, or cultural characteristics which distinguish it from the majority (a minority is a group with linguistic, ethnic, or cultural characteristics which distinguish it from the majority). Second, a minority is a group that usually not only seeks to maintain its identity but also tries to give stronger expression to that identity.

In the study of Charles Taylor "The politics of recognition. In E. Gutman (Ed.), Multiculturalism Examining the politics of recognition", to distinguish state honor in 
The constitutional rights of indigenous beliefs adherents in minority... (Gugun El Guyanie, et.al)

the form of recognition, the term non-recognition or misrecognition emerged as a dichotomy of recognition, which can be interpreted as the role of the state not recognizing or the wrong confession. The consequences of non-recognition or misrecognition can result in loss of rights, become a form of oppression, imprisoning someone in a manipulative or deviant way. Taylor emphatically wrote: Nonrecognition or misrecognition can inflict harm, can be a form of oppression, imprisoning someone in a false, distorted, and reduced mode of being (Taylor, 1994, pp. 25-73).

The population census of the Central Statistics Agency in 2010 noted that Indigenous Beliefs Adherents in Indonesia said there are approximately 299617 people (BPS, 2010). This figure is probably much higher if it is calculated now; many Indigenous Beliefs Adherents have filled out the column in the Indonesian identity card by choosing one of the official religions for reasons of compulsion. Based on data from the Directorate of Belief in God Almighty and Tradition of the Ministry of Education and Culture, 187 Indigenous Belief Adherents groups are spread across 13 provinces, most of which are in Central Java Province with 53 organizations. Other data from the Directorate General of Population and Civil Registration of the Ministry of Home Affairs shows 138,791 people as of July 31, 2017 (Putra, 2017).

Seeing the diversity of religions and beliefs in this country, the constitution affirms the recognition of freedom of religion or belief and constitutional guarantees in carrying out worship according to religion and belief. According to Jimly Asshiddiqie, the phrase "agama dan kepercayaan" (religion and belief) often leads to different interpretations. The first interpretation, kepercayaan (someone's belief) is an inseparable series of the word agama (religion) or belief in the religion concerned. The second interpretation interprets agama and kepercayaan (religion and belief) as two separate and equal things to recognize and guarantee religion and belief systems. In the 1945 BPUPKI sessions, religion and belief were a unified meaning. The separation of the importance of religion and belief developed in the Orde Baru (new order era) due to policies to contrast religious teachings, all considered foreign or imported from outside. In contrast, the schools of belief 
Ijtihad: Jurnal Wacana Hukum Islam dan Kemanusiaan, Volume 21, No. 2, Desember 2021: 155-175

were considered the Indonesian people's original belief system (Asshiddiqie, 2013, p. 129).

About the constitutional rights of Indigenous Beliefs Adherents, the Constitutional Court made a legal breakthrough through the decision Number 97/ PUU-XIV/2016 concerning the Review of Law Number 23 of 2006 concerning Population Administration as amended by Law Number 24 of 2013 concerning Amendments Based on Law Number 23 of 2006 concerning Population Administration (Farihah, 2020, p. 16). Four people proposed the judicial review of the Population Law; Nggay Mehang Tana, Pagar Demanra Sirait, Arnol Purba, and Carlim. Ngay Mehang was the first applicant, from a believer in the Marapu community, East Sumba, NTT; his constitutional rights were impaired because marriages between the Marapu communities, which were carried out customarily, did not receive recognition from the state. So it is difficult for their children to get birth certificates. The second applicant, Pagar Demanra, is a Parmalim believer in North Sumatra, arguing that the principal did not permit a teacher who adhered to Parmalim to worship on Saturdays Parmalim worship, so he had to resign, lost his job. The third applicant, Arnol Purba, is a follower of the Batak Nation's Ugamo faith in Medan City. The biological child of three applicants, named Desy Purba, was refused a job application because the religion column on the electronic ID card was written in a strip, aka blank. Even though according to the criteria and values, Desy should have passed the job, but in the end, she was rejected because she was considered an atheist. This third applicant cannot access business capital from bank financial institutions or cooperatives. They were forced to change the religion column on Indonesian identity card to Christianity. The fourth applicant, Carlim, believes in Sapto Darmo from Brebes, Central Java. Due to the blank religion column in the Indonesian identity card, the family of the deceased applicant had difficulties in the funeral because they were deemed heretical and rejected at the public cemetery in Brebes. When the applicant's child entered school, he was forced to take Islamic lessons.

The decision gave a long breath to the Indigenous Belief Adherents because there was the hope of getting fair treatment, having the same rights as adherents 
The constitutional rights of indigenous beliefs adherents in minority... (Gugun El Guyanie, et.al)

of other religions to include their beliefs in population documents. Although the implementation of the decision is not easy to implement at the village level, subdistrict or sub-district officials, maybe even at the population and civil registry offices. For example, for the Indigenous Belief Adherents Orang Lom in Bangka Belitung, after the Constitutional Court Decision, it is still challenging to list their beliefs on the Indonesian identity card (Salfutra et al, 2019, p. 259).

Studies on Constitutional Court Decision Number 97/PUU-XIV/2016 regarding the rights of Indigenous Beliefs Adherents have been reviewed by several authors. To mention some of the works that have been studied, including; "Putusan MK Nomor 97/PUU-XIV/2016 dan Pengarubnya terbadap Perubahan Identitas Perempuan Penghayat" (Constitutional Court Decision Number 97/PUU-XIV/2016 and its Effect on Changes in the Identity of Women Believers) (Farihah, 2020). In addition, Reko Dwi Salfutra, Dwi Haryadi, and Darwance work, "Implementation of Constitutional Court Decision Number 97/PUU-XIV/2016 for the Lom in the Bangka Belitung Islands (Salfutra et al, 2019, p. 259). See also, Allan Fatchan Ghani Wardhana, "Peran MK dalam Perlindungan HAM bagi warga negara Penganut/ Penghayat Kepercayaan dan Gagagasan Constitutional Complaint” (Wardhana, 2018, pp. 100-113). The English translation is "The Role of The Constitutional Court in the Protection of Human Rights for Citizens of Indigenous Belief Adherents and the Idea of Constitutional Complaints."

However, from previous studies, no one has studied it from the perspective of minority figh as an approach to Islamic law that is a source of ethics for the majority of Indonesian Muslims. This is where the difference in the study written in this article, with the hope of completing the study on the development of Constitutional Court Decisions for Indigenous Belief Adherents and offering another point of view from the side of minority figh (fiqh al-aqalliyat). Even in this study, minority fiqh whose origin was born because it provided a solution to the impasse of Muslim minorities in the West, in this case, is the opposite: using the concept of minority fiqh to defend minority non-Muslims in a Muslim-majority country. 
Based on the above background, the formulation of the problem in this study is: How are the constitutional rights of Indigenous Beliefs Adherents in Indonesia from a minority figh perspective? The purpose of this study is to explore knowledge about the constitutionality of the rights of Indigenous Beliefs Adherents from the perspective of minority figh. It seems unusual when the concept of minority figh is implemented to defend non-Muslims. But herein lies the breakthrough of this study, that minority fiqh can be developed as widely as possible to protect minorities, both Muslims and non-Muslims, who experience discrimination.

\section{Method}

This study is normative legal research, namely legal research, which, according to Soerjono Soekanto and Sri Mamudji, is carried out by examining library materials or secondary data (Barus, 2013, p. 309). The study materials in question are laws and regulations and Constitutional Court Decisions. Collection of legal materials by the method of research library that includes literature from books, scientific journals, mass media, and online news and other literature that has nothing to do with this theme. This study applies a case approach that analyzes cases in Constitutional Court Decision Number 97/PUU-XIV/2016. The analysis in this study uses descriptive qualitative analysis to discuss and obtain the results of scientific research according to the formulation of the problem being studied.

\section{Indigenous beliefs adherents in Indonesia}

In semantics, according to Kamil Kartapradja, kepercayaan has several meanings, among other things: faith to religion; the assumption or belief that there is; considered accurate and honest; agree with wisdom.

Kartapradja defines aliran kepercayaan (indigenous beliefs) as a belief and the beliefs of the Indonesian people outside of religion, not belonging to one religion (Wahyudi, 2018, p. 7). Types of beliefs include (Hadikusuma, 1993, pp. 85-86): first, traditional and animistic beliefs, without philosophy and no mystical lessons; Second, the belief group whose teachings contain philosophy, in which there is also a mystical element, this group calls itself the Kebatinan group. The development and dynamics of the times call itself Golongan 
Kepercayaan Kepada Ketuhanan Yang Maha Esa (the group of belief in the one godhead) (Hadikusuma, 1993, pp. 85-86).

Unlike Kartapradja, Nurdjana categorizes groups called Indigenous Belief Adherents in Indonesia that contain at least four elements (Nurdjana, 2009, p. 53):

First, the category of Indigenous Beliefs Adherents is categorized as local beliefs or local religions (tribes). The beliefs of the Batak tribe, for example, are Parmalim, the King of Batak, Namulajadinabolon. Dayak belief for example; Kaharingan, Manyaan. In West Java, there are Bedouin, Sunda Wiwitan, Buhun beliefs. In Central Sulawesi, there are the Anak Dalam/Kubu and Wana tribes. In Minahasa, North Sulawesi, there are Tonaas Walian), Tolottang (South Sulawesi), Wetu Telu (Lombok), Naurus (Seram Island, Maluku) and various beliefs in Papua.

Second, the category of Indigenous Beliefs Adherents to God Almighty; such as Kejawen Kebatinan adherents, among others: Ngesti Tunggal Association (Pangestu), Sumarah, Susila Budi Dharma (Subud), Travel, Sapta Dharma, Tri Tunggal and Manunggal, Budi Murko Eklasing Association, Sumarah Purbo, Hardo Pusoro Association, Ngesti Tunggal, Mardi Santosaning Budi (MSB), Budi Luhur and others.

Third, the category of Indigenous Beliefs Adherents groups that approach or indicate religion; includes religious sects, religious sects, groupings of religious congregations such as Ahmadiyah, Jawi Wisnu Buda, Children of God, Jehovah, Krishna Day, and others.

Fourth, the category of Indigenous Beliefs Adherents mystical or occult such as shamanism, psychics, fortune-tellers, medicine, witchcraft, sorcery, magic, and metaphysics.

The freedom to choose one's beliefs or the various sects of belief mentioned above may not be interfered with by anyone and may not be reduced by state power. Therefore, to recognize, guarantee and protect freedom of religion and belief, the constitution explicitly includes several articles, which are translations of the regulation of Human Rights as a fundamental right that is owned by every human being a moral, political, legal framework, and as a guideline (Asshiddiqie, 2006, p. 85).

This is to create a world that is peaceful, prosperous, and free from fear and oppression, as well as the treatment of injustice. Indonesia, as a constitutional democratic law country, guarantees for the protection of human rights should be explicitly stated in the constitution of the 1945 Constitution of the Republic of Indonesia (UUD NRI 1945). According to 
Ijtihad: Jurnal Wacana Hukum Islam dan Kemanusiaan, Volume 21, No. 2, Desember 2021: 155-175

Asshiddiqie (2006, p. 85), this guarantee is the most critical non-negotiable material; it must be in the constitution or fundamental law.

\section{The conception of constitutional rights}

The human rights listed in the Indonesian constitution are known as constitutional rights. Asshiddiqie (cited in Pratiwi et al, 2019, p. 27) emphasized that constitutional rights are guaranteed in and by the 1945 Constitution of the Republic of Indonesia, both implicitly and explicitly. Recognition of constitutional rights is a form of legal protection from potential violations from power holders or state administrators in the relationship between the state and citizens. Constitutional rights also contain state recognition of constitutional rights, namely citizens, as people who are legally recognized and ratified by law as Indonesian citizens. Thus, the protection and enforcement of constitutional rights is the obligation of all parties, including citizens.

From the point of view of the Indonesian constitution, constitutional rights regulate rights and obligations; to respect each other and respect the constitutional rights of others. Every person's constitutional rights will give rise to essential commitments and responsibilities to respect the human rights of others reciprocally so that there are restrictions and prohibitions in the implementation of the protection of constitutional rights. Rules set by law are intended to guarantee recognition and respect for the rights and freedoms of others and to fulfill fair demands by considerations of morality, security, public order, and the interests of the nation (Pratiwi et al, 2019, p. 27).

Therefore, the Constitutional Court is one of the state institutions of the judicial branch of power (judicial power) that has a strategic authority to uphold human rights. There are at least two critical powers for promoting, protecting, and fulfilling human rights in Indonesia, namely: reviewing laws against the 1945 Constitution of the Republic of Indonesia and the authority to decide disputes over the head of state institutions (Syafi'ie, 2012, p. 704). In the case of judicial review of the 1945 Constitution of the Republic of Indonesia, for example, Law no. 8 of 1985 on a single principle, Subversion Law, Presidential Decree No. 14 of 1967 on religion, belief, china customs, the Decree of the President No. 127 / U / Kep / 12/1966 regarding change name for citizen wear chinese name law, Law No. 11/ 
PNPS/1963 and several others which were products of the New Order era.

The Constitutional Court has a strategic and vital role in promoting, protecting, and fulfilling human rights through its authority in deciding disputes between state institutions. Historical records show that the National Human Rights Commission (Komnas HAM) experienced conflicts with several other institutions, namely the TNI, the Attorney General's Office, and the police. Komnas HAM is a state institution vital to human rights issues and problems assessment, research, counseling, monitoring, and mediation on human rights. However, sometimes Komnas HAM encounters some issues with other state institutions. Therefore, the existence of the Constitutional Court, which has the authority to decide disputes between state institutions, is expected to provide a way out, which has implications for victims of human rights violations to feel justice (justice) and legal certainty (rechts zekerheid) (Syafi'ie, 2012, p. 705).

One of the roles and contributions of the Constitutional Court which is considered very important at this time is the Constitutional Court Decision Number 97/PUU-XIV/2016 concerning the Review of Law Number 23 of 2006 concerning Population Administration as amended by Law Number 24 of 2013 concerning Amendments to Law Number 23 of 2006 concerning Population Administration (Law on Population Administration), specifically Article 61 paragraphs (1) and (2), as well as Article 64 paragraphs (1) and (5). As the protector of human rights, the Constitutional Court is here to restore the human rights of Indigenous Belief Adherents. The Universal Declaration of Human Rights also focuses on freedom of expression of conscience, including the controversial liberty or freedom to change religions (Lindkvist, 2013, p. 430).

This decision became a significant step undertaken by the Court, to make the Constitutional Court justice is seen not just solely be the mouthpiece of the law (bouche de la loi) alone, would be but the Court has made it out of the concept of normative legal textual only. The legal product of the institution that oversees the constitution implicitly emphasizes that the state protects freedom of religion. Even in Suzana Mosquera's study, including in the emergency of the Covid-19 pandemic, there should be no regulations or laws that limit freedom of religion and practice of belief (Mosquera, 2021, p.2). 
Putusan MK menegaskan, bahwa:

"Menyebutkan bahwa kata "Agama" yang terdapat dalam Pasal 61 ayat (1) dan Pasal 64 ayat (1) Undang- Undang Nomor 23 Tahun 2006 tentang Administrasi Kependudukan sebagaimana yang telah diubah dengan Undang-Undang Nomor 24 Tahun 2013 tentang Perubahan Atas Undang-Undang Nomor 23 Tahun 2006 tentang Administrasi Kependudukan (Lembaran Negara Republik Indonesia Tahun 2013 Nomor 232 dan Tambahan Lembaran Negara Republik Indonesia Nomor 5475) bertentangan dengan Undang-Undang Dasar Negara Republik Indonesia Tahun 1945 dan tidak mempunyai kekuatan hukum mengikat secara bersyarat sepanjang tidak termasuk " kepercayaan"."

The English translation is as follows: The Constitutional Court Decision affirms that: "Stating that the word "agama (religion)" contained in Article 61 paragraph (1) and Article 64 paragraph (1) of Law Number 23 of 2006 concerning Population Administration as amended by Law Number 24 of 2013 concerning Amendments to Law Number 23 of 2006 concerning Population Administration (State Gazette of the Republic of Indonesia of 2013 Number 232 and Supplement to the State Gazette of the Republic of Indonesia Number 5475) is contrary to the 1945 Constitution of the Republic of Indonesia and has no legal force and is conditionally binding. as long as it does not include "kepercayaan (beliefs)"

The Constitutional Court Decision can be a legal basis for Indigenous Belief Adherents to get recognition, respect, and protection by embedding the beliefs they hold and believe on the electronic ID card. This decision is none other than the fact that the Constitutional Court, as a state institution given the authority to examine, hear and decide a case, must consider it philosophically, juridically, and sociologically. A professor of Anthropology from Boston University, Robert W. Hefner, in the opening speech of the International Conference on Indigenous Religions: The State, Indigenous Religions, and Inclusive Citizenship on July 1, 2019, at the University Club UGM, stated that the civil rights or citizenship of Indigenous Beliefs Adherents and the ancestral religion which is championed through the institution of constitutional guardianship is a realization of the ideals of Pancasila and the founders of Indonesia (Fachrudin, 2019). To express his joy, a resident of the Kaharingan community in Central Kalimantan called the Constitutional Court Decision a "great kingdom" that was sent down from the sky for them (Maarif, 2019, p. 17). 
For decades, the people of Indigenous Beliefs Adherents have been looked down upon, suffered from mental suffering because they were considered infidels and atheists, and were monitored by the prosecutor's office. There is no teaching of Indigenous Beliefs Adherents that is contrary to the values of God. The teachings of Indigenous Beliefs Adherent's social life are also in harmony with democratic culture and politics. In this context, Marcus Smith and Peter Marden wrote an article that outlines the critical question of whether Christian religious values are compatible with a democratic culture (Smith \& Marden, 2012, p. 303). If you use similar critical questions from Smith and Marden, then there are no local beliefs that are anti-democratic.

The following is the confession of a Rato, the leader of the Marapu community in Southwest Sumba, NTT, together with his residents telling the story of life as Indigenous Belief Adherents Marapu (Maarif, 2019, p. 1):

"Kami semua dengan mudah dituduh kafir, dianggap penganut aliran sesat, bahkan disebut primitif. Anak-anak kamipun dipaksa memilih agama resmi negara ketika di sekolah. Padahal sebenarnya kami mewarisi agama lelubur kami, menjaga dan melestarikan adat dan tradisi, agar keluarga kami tetap utuh, dan komunitas serta lingkungan kami dapat berkelanjutan. Jika saja kami meninggalkan dan tidak mempedulikannya, kami dosa, dan bidup kami akan berlangsung tanpa makna. Itulah situasi kami dulu. Kami menghadapi hinaan dan celaan tanpa mampu melawannya. Dengan sangat berat hati, anak-anak kami terpaksa pindah agama, karena mereka mau dan perlu sekolah untuk. masa depannya".

The English translation is as follows: "We are all easily accused of being infidels, considered heretics, even called primitive. Our children are forced to choose the official state religion when they are at school. We inherit our ancestral religion, maintain and preserve customs and traditions so that our family remains intact and our community and environment can be sustainable. If we just leave and don't care about it, we are sinful, and our lives will be meaningless. That was our situation back then. We faced insults and reproaches without being able to resist them. With a heavy heart, our children were forced to change religions because they want and need school for their future."

Listening to the horrible experience regarding the silence of freedom of belief above, there is a similar experience from the Right-line Christian group in Australia as written by Kurti Peter. At first, right-wing Christians were threatened when 
practicing and expressing their religious freedom. A long history records them being persecuted and ostracized by a secular political culture from the public area. Finally, this fact encourages the Christian Right to appear in the public sphere and political impulses, which are the core of understanding the political rights of Christian groups (Peter, 2012). But for Indigenous Belief Adherents in Indonesia, the weak position of the faith's adherents makes them not have the significant political power to fight discrimination from the state. The Constitutional Court Decision, in this case, is one of the results of the long struggle of the Indigenous Belief Adherents who struggle in conditions of being weak and oppressed. The political fight against discrimination in the population administration of believers reflects the values of any religion and belief, or vice versa, if using Miroljub's terminology, understanding religious values as part of political behavior (Bozinovich, 2009, pp. 279-284).

Understanding and observing the Constitutional Court Decision, on the one hand, is a breath of fresh air for the adherents of Indigenous Belief Adherents but has also received criticism from several parties. Majelis Ulama Indonesia or the Indonesian ulema council (MUI) criticized the Constitutional Court by stating that the Constitutional Court made decisions that only adhered to the principles of legislation, without him paying attention to agreements in the life of the nation and state (Kompas, 2017). Concerns also arise when some religious fundamentalist groups do not appreciate the Constitutional Court Decision. Especially with the emergence of the phenomenon of religious fundamentalist groups who have become political forces, as written by Ozzano (Luca, 2009, pp. 137-153).

Therefore, as an alternative point of view, it is necessary to look holistically at Constitutional Court Decision Number 97/PUU-XIV/2016 concerning the judicial review of the Population Administration Law in the eyes of minority fiqh. Linguistically, minority fiqh (figh al-aqalliyyat) consists of two words, namely, figh and aqalliyyat. The word figh itself is etymologically equated with the meaning of understanding. Terminologically, defined as knowing the laws of God in respect of acts of mukallaf, whether they are mandatory, sunnah, haram, makruh, or permissible (Al-Asnawi, 1999, p. 11). Meanwhile, aqalliyyat etymologically means a minority or group, is a political term defined as a community group 
in a government which in terms of ethnicity, language, race, or religion is different from the developing majority group (Mawardi, 2010, p. 119).

\section{Minority fiqh to protect constitutional rights}

Minority fiqh ( fiqh al-aqalliyyat) is a model of fiqh that contextualizes syar'i law with the dimensions of a minority community in the West (Nurhayati, 2013, p. 193). Minority fiqh is not an entirely new model of figh, which is separate from traditional figh, but is a product of reinterpretation of the arguments based on benefit as the spirit of sharia. The initiators of this fiqh are two contemporary scholars, Taha Jabir Al-Alwani in his book: Toward a Fiqh for Minorities: Some Basic Reflection and Yûsuf al-Qarâdawî in his book: Fî Fiqh al-Aqalliyât alMuslimah (Al-Qaradawi, 2004, p. 35-38).

When viewed from the historical aspect of its development, minority figh is part of figh in general; it's just that there is a unique character because it will be applied to a society with a unique personality, namely the Muslim minority in the West (Kettani, 2005). This means that minority fiqh was initially born to answer the challenges of Muslims in the West who are minorities, whose rights are discriminated against. The convergence of Muslims in Europe and America, which became the intersection of civilization and culture, also gave rise to the idea of cosmopolitan figh, which Bakare Najimdeen referred to as a way for Muslims to demonstrate Islamic values and contribute to the Western society that is a part of their lives. The main goal of cosmopolitan figh is to become a bridge between the past and the present (Najimdeen, 2014, p. 33). If minority fiqh provides a breakthrough for Muslim minorities in the West, then cosmopolitan fiqh reconciles Islam with Western civilization.

Minority fiqh is based on the logic and methodology of Islamic law based on the doctrines of maslaha (maslahah) and urf (tradition). It also paved the principal goal enactment of the law of Islam (maqashid ash-syari ah) were charged protection on five things basic (dlaruriyyat al-khamsah) either in dlaruriyyat, hajiyyat and luxuries, are all principles public that his spirit of justice and goodness. Thus, the teachings of Islam contained in the Quran's universality point to the enforcement of the principle of humanity, where the discrimination of Muslims and non-Muslims is not justified (Fishman, 2006). 
Most of the literature that discusses minority figh takes the study of Muslim communities and citizens in non-Muslim areas (Fishman, 2006). Of course, it is very understandable because the historical context of its birth provides a breakthrough for the impasse experienced by minority Muslims in the West. It started when in 1994, the North American Fiqh Council, under the command of Al Alwani, issued a fatwa that allowed American Muslims to vote in US elections, even though there were no Islamic political parties or even a complete void of Muslim candidates (Mas'ud, 2002, p. 17).

In this study, minority fiqh will be implemented to defend non-Muslim minorities in Muslim-majority countries. This study ventured to develop minority figh is not just about how Muslims live as a minority, but how should Muslims who are in a position to treat the majority of non-Muslim minorities, so that the expected birth of symbiotic mutualism. The expansion of this concept in the context of all - Indonesian is significant to lay the conceptual foundation that protecting minorities is part of the enforcement of the values of religion or the purpose of prescribed religion. Moreover, in Indonesia, Muslims as the majority live side by side with other religious minorities; even more in the minority are followers of ancestral faiths.

Fiqh al-aqalliyyat is, of course, built on the foundation of legal rules (legal maxims) known as al-qawa'id al-fiqhiyyah as is usual in classical fiqh, which also comes from five main principles known as al-kulliyyat al-khams (As-Suyuthi, 1958, p. 6), namely: all things depend on the intention; belief cannot be dispelled by doubt; difficulty brings ease; madlarat (harm) must be eliminated; custom can become law.

The basic rules above have provided a grand design that fiqh must consider the essential things, namely intentions and things that facilitate and bring mashlaha (public good benefit). Fiqh al aqalliyyat can be referred to as non-discrimination fiqh because figh is based on elaborating and formulating figh based on human rights. An essential aspect of this figh, among others, refers to parts of tolerant values and openness to interact with other people with the concept of wasatiyah (Mahmashani, tt, pp. 220-230). So minority fiqh, and fiqh in general, actually not only regulates how the Muslim minority lives according to the teachings of the shari'ah but also regulates the majority of Muslims to live side by side, treating other people with different beliefs relatively (Yuliantoro, 2015, p. 491). 
Islam views that all humans must be honored regardless of religion, belief, ethnic origin, and skin color. It is also the same between men and women; there is no difference. Whites are not superior to blacks. Therefore, minority fiqh is expected to become a relevant concept to overcome the discrimination experienced by Indigenous Beliefs Adherents as citizens who should have an equal position before the law.

This is as emphasized by Abu Al-A'la al-Maududi, that the rights of the people are very fundamental. In more detail, first, protection of his life, wealth, and honor. Second, the protection of personal freedom. Third, protection of freedom of expression and belief. Fourth, ensuring the principal's life needs, with no distinguishing class and beliefs (Djazuli, 2009, p. 64).

Islam as a religion of rabmatan lil 'alamin also highly upholds respect for the existence of human rights collectively and individually. This is an effort to achieve justice and the public interest through the protection and guarantee of basic needs (al-daruriyyah), which is the intent and purpose of Islamic law (maqasid al-Shariah) contained in the Qur'an and Al-hadith (Syatibi, n.d, p. 21). The five basic points that must be maintained include al-din (religion), al-nafs (soul), al-'aql (reason), al-nasl (descendants or honor), and al-mal (wealth). Therefore, the Constitutional Court Decision above is in line with the theory of maslahah (public good), namely safeguarding the objectives of syara', which is primarily aimed at achieving benefits and rejecting harm (Al Ghazali, 2008, p. 275), and is (justice) which is one of the main principles in the application of Islamic law.

The form of protection against minority groups by Islam can be traced in the work of Kamal Said Habib, namely Al-Aqaliyyat wa al Siyasah fi al Khibrah al-Islamiyyah. This work examines how political authorities from the early days of Islam to the Ottoman period treated minority groups, Muslim and non-Muslim minorities (Yuliantoro, 2015, p. 165).

Constitutional Court Decision Number 97/PUU-XIV/2016 concerning the Judicial Review of the Population Administration Law regarding fiqiyyah rules in fiqh al-aqaliyyat also have harmony.

First, the rule of al-taisyir wa raf al-haraj. This principle becomes very important because it makes complicated things easier (Mawardi, 2010, p. 119). The Constitutional Court Decision that allows and provides convenience for Indigenous Belief Adherents in 
administrative records is a concrete form of recognition of the rights of Indigenous Belief Adherents that have been ignored so far. Especially in administrative matters, which before the Constitutional Court Decision was tough. With the Constitutional Court Decision, it is hoped that Indigenous Belief Adherents can obtain their rights in public services, and there will be no discrimination.

Second, the rule of taghoyurul abkam bi taghoyuril amkan wa azman wa abwal. Rule's sense changes in the law should be aligned with the change of venue, times, and circumstances. So it can be understood that the law has elasticity and flexibility. The problems that arise at different times must be answered by Islamic law. In addition, Islamic law must accommodate the aspirations and social conditions of the community to realize the mashlaha or public good (Yuliantoro, 2015, p. 493). Therefore, Constitutional Court Decision Number 97/ PUU-XIV/2016 has values in line with this rule. This is because the Constitutional Court has succeeded in answering the problems experienced by Indigenous Beliefs Adherents marginalized. Since ancient times, this group has existed but has been subjected to prolonged discriminatory treatment.

Third, the rule of 'urf (habits). This rule has a very strategic position in Islam. This is because Islam views that the existing tradition can be continued if it does not conflict with syara. The existence of Indigenous Beliefs Adherents that have existed since ancient times. The Court then accommodated to maintain the tradition and multicultural diversity in Indonesia. This is like the motto of the Indonesian people "Bhinneka Tunggal Ika." Because 'urf is what becomes the living law in society (Mawardi, 2010, p. 149).

Fourth, the rule of al-nadzr ila al-ma'alat. This rule is a gift that is based on consideration of legal consequences. The core values of this rule are the process towards a maslaha (public good). The final result (goal) or legal matter resulting from a lawful provision is the emphasis (Mawardi, 2010, p. 149). Therefore, the Constitutional Court Decision Number 97 / PUUXIV / 2016 views of this rule is a synergy that will bring as a result of the law is good against groups of Indigenous Beliefs Adherents. The Constitutional Court Decision, which is final and binding, has legal force towards Indonesian law with the spirit of substantial justice. So that the decision is very futuristic, reaching far into the future of human rights protection in the future. 
After the minority figh study is firmly in favor of minorities, including in the context of Indonesia being the Indigenous Belief Adherents minority, it is hoped that there will be no more discrimination and treat them as second-class citizens, who in public services and their rights as citizens are always disadvantaged. Minority figh not only stops defending Muslim minorities in the West but must be developed and contextualized for non-Muslim minorities amid the Muslim majority.

Innovations or breakthroughs to transplant the concept of minority figh in the Constitutional Court Decision study on Indigenous Beliefs Adherents into a new perspective that elevates the dignity or honor of citizens who practice ancestral religions, to be equal with citizens of other countries, including the Muslim majority. So, after the Constitutional Court Decision, which was religiously legitimized by minority fiqh, there was no longer any fear of being persecuted for the Indigenous Beliefs Adherents family. There is no longer the notion that they are atheists or infidels. This includes not having any apparatus that makes it difficult to obtain birth certificates, the Indonesian identity card, and admitting children to school without forcing them to take official religious lessons.

\section{Conclusion}

The issue of discrimination against minorities, especially Indigenous Belief Adherents, can be resolved harmoniously between the viewpoints of constitutional rights and minority figh. So far, the religious and secular legal views think the two things will not meet in harmony. Moreover, the ijtihad fiqh minority origin of its birth is for the defense of minority Muslims in the West. But with the courage to bring the innovation of minority figh out of a wider dimension: defending minority rights without limiting the Muslim minority only, minority fiqh will truly achieve the goal of enacting the law of Allah. Contradicting fiqh with the Constitutional Court Decision, in the end, it is irrelevant for the protection of the constitutional rights of Indigenous Beliefs Adherents. On the other hand, compromising or reconciling figh with the Constitutional Court Decision to protect the constitutional rights of Indigenous Beliefs Adherents is a harmonious breakthrough.

Until the Constitutional Court Decision runs for four years, the implementation of the decision to recognize the variant of trust in civil and population documents is still 
Ijtihad: Jurnal Wacana Hukum Islam dan Kemanusiaan, Volume 21, No. 2, Desember 2021: 155-175

experiencing problems. One of them is the community's rejection, including the village, kelurahan (area), sub-district officials, to the Disdukcapil (Department of Population and Civil Registration) service officer. This is a challenge in the future; there must be the socialization of the Constitutional Court Decision with the legitimacy of sources of religious ethics, minority fiqh. So from the results of this study, one recommendation for further research is implementing the Constitutional Court Decision on the constitutional rights of the Indigenous Belief Adherents. After the Constitutional Court Decision, according to structural regulations, the government is willing to submit to implementing the Constitutional Court Decision to restore the rights of Indigenous Beliefs Adherents and whether the community, including the clergy, will support the implementation of the Constitutional Court Decision.

\section{References}

Al-Asnawi, J. al-din A. al-R. (1999) Nihayat al-Sul Syarh Minhaj al-wushul fi'Im al-Ushul. Beirut: Dar al-Kutub al-Ilmiyyah.

Asshiddiqie, J. (2006) Pengantar Ilmu Hukum Tata Negara Jilid II. Jakarta: Sekretariat Jenderal dan Kepaniteraan MKRI. . (2013) Komentar atas UUD NRI Tahun 1945. Jakarta: Sinar Grafika.

Barus, Z. (2013) 'Analisis Filosofis tentang Peta Konseptual Penelitian Hukum Normatif dan Penelitian Hukum Sosiologis', Jurnal Dinamika Hukum, 13(2), pp. 307-318.

Bober, S. and Berdiqulov, A. (2020) 'Recognition, Non-recognition, and Misrecognition of Minority Communities. What Lessons Can Be Drawn from a Comparison between European and Central Asian Approaches?'. European Centre for Minority Issues (ECMI) Research Paper, 124.

Bozinovich, M. (2009) 'Review Politology of Religion', Politics and Religion Journal, 3(2), pp. 279-284.

Budijanto, O. W. (2016) 'Penghormatan Hak Asasi Manusia Bagi Penghayat Kepercayaan di Kota Bandung', Jurnal Hak Asasi Manusia, 7(1), pp. 35-44.

Djazuli, A. (2009) Fiqh Siyasah Implementasi Kemaslahatan Umat dalam Rambu-rambu Syari'ah. Jakarta: Kencana. 
The constitutional rights of indigenous beliefs adherents in minority... (Gugun El Guyanie, et.al)

Dwipayana, A. G. A. (2011) 'Problematika Relasi Negara dan Desa', paper seminar "Relasi Politik Negara dan Desa” held by Lingkar Pembaharuan Agraria dan Desa (KARSA). Yogyakarta.

Fachrudin, A. A. (2019) Pasca-Putusan MK 2017: Persoalan Penghayat Kepercayaan yang Belum

Usai. Available at: https://crcs.ugm.ac.id/pasca-putusan-mk-2017-persoalanpenghayat-kepercayaan-yang-belum-usai/ (Accessed: 3 October 2021).

Farihah, R. (2020) 'Putusan MK Nomor 97/PUU-XIV/2016 dan Pengaruhnya terhadap Perubahan Identitas Perempuan Penghayat', Staatsrecht: Indonesian Constitutional Law Journal, 4(1), pp. 2-22.

Fishman, S. (2006) 'Fiqh al-Aqalliyat: A Legal Theory for Muslim Minorities', Hodson Institute: Research Monograph on the Muslim World, 1(2).

Al-Ghazali, A. H. (2008) Al Mustasfā min Tlm al Usul. 1st edn. Beirut: Dār al Kutub al 'Ilmiyah.

Hadikusuma, H. (1993) Antropologi Agama. Bandung: Citra Aditya Bakti.

Kettani, M. A. (2005) Muslim Minorities In The World Today translated by Zarkawi Soejoeti, Minoritas Muslim di Dunia Dewasa Ini. Jakarta: Raja Grafindo Persada.

Kuwado, F. (2017) Ketum MUI Kritik Putusan MK soal Penghayat Kepercayaan, Kompas.com. Available at: https://nasional.kompas.com/read/2017/11/15/16000091/ketummui-kritik-putusan- mk-soal-penghayat-kepercayaan (Accessed: 23 September 2019).

Lindkvist, L. (2013) 'The Politics of Article 18: Religious Liberty in the Universal Declaration of Human Rights', Humanity: An International Journal of Human Rights, Humanitarianism, and Development, 4, pp. 429-437.

Luca, O. (2009) 'Religious Fundamentalism and Democracy', Politics and Religion Journal, 3(1), pp. 37-153.

Maarif, S. (2019) Merangkul Penghayat Kepercayaan Melalui Advokasi Inklusi Sosial. Laporan Kehidupan Beragama di Indonesia Edisi II/Juli. Yogyakarta: CRCS.

Mahkamah Konstitusi Republik Indonesia. (2017). Putusan Nomor 97/PUU-XIV/ 2016. Available at: https://www.mkri.id/public/content/persidangan/putusan/97_PUUXIV_2016.pdf. (Accessed: 2 Juli 2021) 
Ijtihad: Jurnal Wacana Hukum Islam dan Kemanusiaan, Volume 21, No. 2, Desember 2021: 155-175

Mahmashani, S. (no date) Falsafah al-Tasyri' fi al-Islam. Cet. V. Beirut: Dar al-'Ilm li al-Malayiin. Mas’ud, M. K. (2002) 'Islamic Law and Muslim Minorities', ISIM Review, 11(17).

Mawardi, A. I. (2010) Fiqh Minoritas: Fiqh Al-Aqalliyyat dan Evolusi Maqasid al-Syari'ah dari Konsep ke Pendekatan. Yogyakarta: LKiS.

Mosquera, S. (2021) 'The Impact of the Church-State Model for an Effective Guarantee of Religious Freedom: A Study of the Peruvian Experience during the COVID-19 Pandemic', Laws, 10(40).

Najimdeen, B. (2014) 'From the Fiqh of Minority to Cosmopolitan Fiqh An Analysis', Policy Perspectives, 11(1), pp. 33-45.

Nurdjana, I. G. . (2009) Hukum dan Aliran Kepercayaan Menyimpang di Indonesia. Yogyakarta: Pustaka Pelajar.

Nurhayati (2013) 'Fikih Minoritas: Suatu Kajian Teoritis', Jurnal Abkam, 8(2), pp. 193-200.

Peter, K. (2012) Religious freedom must not be taken for granted ABC Religion and Ethics. Available at: http://www.abc.net.au/religion/articles/2012/02/24/3438908.htm (Accessed: 20 October 2020).

Pratiwi, D. K. et al (2019) 'Pengenalan Hak-hak Konstitusional Warga Negara di Sekolah', Jamali Jurnal Abdimas Madani dan Lestari, 1(1), p. 27.

Putra, L. M. (2017) Sebetulnya Berapa Jumlah Penghayat Kepercayaan di Indonesia. Available at: https://sains.kompas.com/read/2017/11/22/124500723/sebetulnya-berapajumlah-penghayat-kepercayaan-di-indonesia-?page=all (Accessed: 2 October 2021).

Al-Qaradawi, Y. (2004) Fî Fiqh al-aqaliyyât al-Muslimah. Translated by Adillah Obid, Fiqh Minoritas: Fatwa Kontemporer terhadap Kehidupan Kaum Muslimin di Tengah Masyarakat Non Muslim. Jakarta: Zikrul Hakim.

Salfutra, R. D. et al (2019) 'Implementasi Putusan Mahkamah Konstitusi Nomor 97/PUUXIV/2016 bagi Orang Lom di Kepulauan Bangka Belitung', Jurnal Konstitui, 16(2), pp. 255-273.

Smith, M. and Marden, P. (2012) 'Politics, Policy and Faith: The Christian Right in Australia', Journal Politics and Religion, 6(2), pp. 303-332.

As-Suyuthi, J. (1958) Al-Asybah wa an-Naz̧ha ir. Beirut: Dar al-Fikr.

Syafi'ie, M. (2012) 'Instrumentasi Hukum HAM, Pembentukan Lembaga Perlindungan 
The constitutional rights of indigenous beliefs adherents in minority... (Gugun El Guyanie, et.al)

HAM di Indonesia dan Peran mahkamah Konstitusi', Jurnal Konstitui, 9(4), pp. 304323.

Syatibi, A. (no date) Al Muwafaqat fi Ushul al-Syari'ah. Kairo: Mustafa Muhammad.

Taylor, C. (1994) The politics of recognition. Princeton: Princeton University Press.

Wahyudi, M. (2018) Analisis Masuknya Aliran Kepercayaan di Kolom Agama dalam Kartu Keluarga dan Kartu Tanda Penduduk: (Studi Putusan Mabkamah Konstitusi Nomor 97/PUUXIV/2016 tentang Yudicial Review Undang-undang Administrasi Kependudukan). UII.

Wardhana, A. (2018) 'Peran MK dalam Perlindungan HAM bagi warga negara Penganut/ Penghayat Kepercayaan dan Gagagsan Constitutional Complaint', Jurnal Majelis, 4(4), p. 100-113.

Yuliantoro, T. (2015) 'Indigenous Constitution dalam Prespektif Ketatanegaraan dan Fikih Minorita', In Right: Jurnal Agama dan Hak Arazi Manusia, 4(2), pp. 165-190. 
